\title{
EFEKTIVITAS PEMBELAJARAN DARING PADA MATA KULIAH PENDIDIKAN AGAMA ISLAM DALAM SITUASI PANDEMI COVID-19
}

\author{
Adhika Alvianto 1)* $^{*}$ \\ ${ }^{1}$ Program Studi Manajemen \\ Universitas Sarjanawiyata Tamansiswa, Yogyakarta \\ *E-mail: adhika@ustjogja.ac.id
}

\begin{abstract}
This study aims to determine the effectiveness of online learning in the Islamic Religious Education course in the Covid-19 pandemic situation at the Faculty of Economics, University of Sarjanawiyata Tamansiswa Yogyakarta (FE-UST). This study is also to evaluate the quality of online learning that has been implemented and as a material for developing an online learning system in the new normal era. The research method used is quantitative with a survey method. The number of samples in this study were 280 students. Collecting data using a survey method with a likert scale. Data analysis by calculating the percentage of data on each indicator, then interpreted the data percentage score and analyzed descriptively on each indicator. The results showed that the effectiveness of online learning in the Islamic Religious Education course in the Covid-19 pandemic situation at FE-UST Yogyakarta reached 74\% or it was in the good category. The results of this study are also expected to be a reference in the development of online learning in tertiary institutions and as study material for further research related to the effectiveness of online learning.
\end{abstract}

Keywords: Effectiveness, Online Learning, Islamic Education, Covid-19

\begin{abstract}
Abstrak
Kajian ini bertujuan untuk mengetahui efektivitas pembelajaran daring pada mata kuliah Pendidikan Agama Islam dalam situasi pandemi Covid-19 di Fakultas Ekonomi Universitas Sarjanawiyata Tamansiswa (FE-UST) Yogyakarta. Penelitian ini juga untuk mengevaluasi kualitas pembelajaran daring yang telah dilaksanakan dan sebagai bahan untuk menyusun sistem pembelajaran daring di masa new normal. Metode penelitian yang digunakan adalah kuantitatif dengan metode survei. Jumlah sampel penelitian ini sebanyak 280 mahasiswa. Pengambilan data menggunakan metode survei dengan skala likert. Analisis data dengan menghitung persentase data pada setiap indikator, kemudian diinterpretasikan skor persentase datanya dan dianalisis secara deskriptif pada setiap indikator. Hasil penelitian menunjukkan bahwa efektivitas pembelajaran daring pada mata kuliah Pendidikan Agama Islam dalam situasi pandemi Covid-19 di FE-UST Yogyakarta mencapai 74\% atau masuk dalam kategori baik. Hasil penelitian ini juga diharapkan dapat menjadi acuan dalam pengembangan pembelajaran daring di Perguruan Tinggi dan sebagai bahan kajian untuk penelitian-penelitian selanjutnya yang terkait dengan efektivitas pembelajaran daring.
\end{abstract}

Kata kunci: Efektivitas, Pembelajaran Daring, Pendidikan Agama Islam, Covid-19 


\section{PENDAHULUAN}

Pandemi Covid-19 yang melanda seluruh dunia termasuk Indonesia telah membawa banyak perubahan di berbagai sektor secara cepat. Sampai saat ini perkembangan kasus positif Covid-19 di Indonesia masih relatif tinggi, belum terdapat tanda-tanda penurunan. Indonesia pun masuk dalam situasi darurat nasional. Jumlah kematian yang disebabkan oleh Covid-19 terus meningkat sejak pertama kali diumumkan kepada publik pada awal bulan Maret 2020. Hal ini telah mempengaruhi banyak perubahan dan pembaharuan kebijakan pada semua sektor, termasuk sektor pendidikan.

Salah satu kebijakan baru yang terlihat jelas dan berlaku untuk semua jenjang pendidikan adalah terkait perubahan sistem pembelajaran yang lazimnya atau lebih seringnya dilakukan di dalam ruangan atau kelas berubah menjadi cukup di rumah saja. Hal tersebut termasuk kegiatan perkuliahan di perguruan tinggi.

Kebijakan untuk tetap di rumah saja, selalu menjaga jarak dan menghidari kerumunan di mana pun dan kapan pun harus diikuti dengan perubahan sistem pembelajaran tatap muka menjadi sistem pembelajaran daring (online). Pembelajaran daring merupakan model pembelajaran berbasis teknologi melalui pembelajaran jarak jauh dengan menggunakan fasilitas jaringan internet untuk dapat berinteraksi secara daring.

Berbagai elemen telah berupaya untuk ikut serta dalam mengatasi dan mencegah penyebaran Covid-19, baik pemerintah maupun seluruh lapisan masyarakat. Pada sektor pendidikan berupaya dengan mengeluarkan kebijakan tentang pembelajaran secara daring dan bekerja dari rumah dalam rangka mencegah penyebaran Covid-19 (Kemendikbud, 2020).

Situasi ini menjadikan proses kegiatan pembelajaran dilaksanakan secara daring. Menindaklanjuti surat edaran Menteri Pendidikan dan Kebudayaan Republik Indonesia dan hasil rapat koordinasi pimpinan Universitas Sarjanawiyata Tamansiswa (UST) Yogyakarta, maka melalui kebijakan yang ditetapkan oleh rektor dengan salah satu kebijakannya adalah kegiatan perkuliahan berjalan sesuai jadwal dan dilaksanakan dengan pembelajaran daring (online) melalui portal universitas dan atau berbagai platform pembelajaran daring.

Sebelum adanya pandemi Covid-19 Universitas Sarjanawiyata Tamansiswa (UST) Yogyakarta telah melaksanakan sistem pembelajaran e-learning (daring). 
Meskipun pelaksanaannya tidak untuk seluruh pertemuan, namun hal ini seharusnya tidak terlalu memberikan dampak luas terhadap pelaksanakan pembelajaran daring yang harus dilaksanakan pada semua pertemuan.

Hal lain yang perlu diperhatikan adalah terkait metodologi pembelajaran pendidikan agama Islam yang masih menggunakan cara konvensional, seperti: ceramah dan tanya jawab yang dipandang efektif dalam mengatasi keterbatasan waktu. Meskipun, metode ceramah dan tanya jawab juga dapat dilakukan dalam pembelajaran daring. Namun, dalam pelaksanaan pembelajaran daring sering diketemukan kendala-kendala yang menyebabkan waktu untuk belajar menjadi berkurang (tersendat) dan tidak tepat waktu.

Sehingga, adanya keluhan-keluhan yang dialami oleh mahasiswa menjadikan dosen untuk melakukan penelitian dengan bertujuan menganalisis bagaimana efektivitas pembelajaran daring (online), khususnya mata kuliah Pendidikan Agama Islam (PAI) pada saat pandemi Covid-19 ini. Mengingat berakhirnya pandemi Covid19 belum diketahui, dan akan diterapkannya new normal, maka hasil penelitian ini diharapkan dapat menjadi bahan pengelolaan atau manajemen pembelajaran daring pada pertemuan berikutnya.

Menurut Jamaluddin, pembelajaran daring merupakan suatu proses tranformasi dari sistem pembelajaran konvensional ke dalam bentuk digital sehingga memiliki tantangan dan peluang tersendiri. Oleh sebab itu, adanya kendala dalam pelaksanaan pembelajaran daring harus segera dapat diketemukan solusinya, sehingga proyeksi pembelajaran dengan sistem daring dapat berjalan dengan efektif.

Perlu dipahami bahwa keefektifan program pembelajaran tidak hanya dilihat dari aspek prestasi belajar saja, melainkan juga harus ditinjau dari aspek proses dan sarana penunjang. Efektivitas metode pembelajaran merupakan suatu ukuran yang berkaitan dengan tingkat keberhasilan dari suatu proses pembelajaran.

Tujuan dalam penelitian ini adalah untuk mengetahui efektivitas penerapan pembelajaran daring pada mata kuliah Pendidikan Agama Islam (PAI) dalam situasi pandemi Covid-19 dan kendala-kendala yang terdapat dalam pelaksanaan pembelajaran daring pada mata kuliah Pendidikan Agama Islam (PAI) dalam situasi pandemi Covid-19 di Fakultas Ekonomi Universitas Sarjanawiyata Tamansiswa Yogyakarta. 
Selain itu, penelitian ini juga diharapkan dapat menjadi masukan untuk perguruan tinggi yang telah menerapkan pembelajaran daring, khususnya Fakultas Ekonomi Universitas Sarjanawiyata Tamansiswa Yogyakarta. Penelitian ini juga dapat digunakan sebagai evaluasi pelaksanaan pembelajaran daring dan bahan persiapan pengelolaan pembelajaran daring dalam menghadapi era new normal.

\section{METODE}

Penelitian ini merupakan penelitian kuantitatif dengan menggunakan metode survei. Penelitian survei ini digunakan untuk mengungkap bagaimana efektivitas pembelajaran daring pada mata kuliah pendidikan agama Islam dalam situasi pandemi Covid-19. Adapun subjek dalam penelitian ini adalah mahasiswa semester satu dari Program Studi Manajemen dan Program Studi Akuntansi Fakultas Ekonomi Universitas Sarjanawiyata Tamansiswa Yogyakarta.

Jumlah sampel dalam penelitian ini sebanyak 200 mahasiswa dari Program Studi Manajemen dan sebanyak 80 mahasiswa dari Program Studi Akuntansi. Teknik pengambilan sampel menggunakan teknik simple random sampling, dikarenakan anggota populasi relatif homogen yakni mahasiswa semester satu yang mengikuti pembelajaran daring mata kuliah Pendidikan Agama Islam (PAI) di Program Studi Manajemen dan Program Studi Akuntansi.

Skala pengukuran dalam penelitian ini menggunakan model skala likert. Model ini dapat digunakan untuk mengukur sikap, pendapat, dan persepsi seseorang atau sekelompok orang terhadap fenomena sosial (Sugiyono, 2012:93). Selanjutnya, instrumen dalam penelitian ini menggunakan metode survei dengan bentuk kuesioner yang dibuat melalui google form. Berikut ini merupakan tabel skala likert yang digunakan dalam penelitian ini:

Tabel 1. Skala Likert

\begin{tabular}{|c|c|}
\hline Kriteria Penilaian & Skala Penilaian \\
\hline Sangat Setuju & 5 \\
\hline Setuju & 4 \\
\hline Cukup Setuju & 3 \\
\hline Tidak Setuju & 2 \\
\hline Sangat Tidak Setuju & 1 \\
\hline
\end{tabular}


Adapun teknik analisis data dalam penelitian ini dengan menghitung persentase dari hasil skor yang telah diperoleh melalui penyebaran kuesioner yang dibuat melalui google form. Kemudian, hasil dari penghitungan persentase yang diperoleh dinterpretasikan skornya melalui tabel interval di bawah ini:

Tabel 2. Kriteria Interpretasi Skor

\begin{tabular}{|c|c|}
\hline Kriteria Interpretasi & Skor Persentase \\
\hline Sangat Kurang Baik & $0 \%-19,99 \%$ \\
\hline Kurang Baik & $20 \%-39,99 \%$ \\
\hline Cukup Baik & $40 \%-59,99 \%$ \\
\hline Baik & $60 \%-79,99 \%$ \\
\hline Sangat Baik & $80 \%-100 \%$ \\
\hline
\end{tabular}

Berdasarkan dari hasil penghitungan data di atas, kemudian dijadikan sebagai landasan dalam menganalisis dan menyimpulkan bagaimana efektivitas pembelajaran daring pada mata kuliah Pendidikan Agama Islam dalam situasi pandemi Covid-19 di Program Studi Manajemen dan Program Studi Akuntansi Fakultas Ekonomi Universitas Sarjanawiyata Tamansiswa Yogyakarta.

\section{HASIL DAN PEMBAHASAN}

Kajian ini membahas tentang efektivitas pembelajaran daring pada mata kuliah Pendidikan Agama Islam dalam situasi pandemi Covid-19 di Program Studi Manajemen dan Program Studi Akuntansi Fakultas Ekonomi Universitas Sarjanawiyata Tamansiswa (UST) Yogyakarta. Berdasarkan hasil survei dari 200 mahasiswa Program Studi Manajemen dan 80 mahasiswa Program Studi Akuntansi diperoleh data sebagai berikut:

Tabel 3. Hasil Survei Efektivitas Pembelajaran Daring pada Mata kuliah PAI

\begin{tabular}{|c|l|c|c|}
\hline No. & \multicolumn{1}{|c|}{ Aspek } & Persentase & Kriteria \\
\hline 1 & $\begin{array}{l}\text { Kemudahan dalam penggunaan aplikasi Sistem } \\
\text { Informasi Pembelajaran Daring (Sipedar) UST } \\
\text { untuk pembelajaran daring (online) }\end{array}$ & $76 \%$ & Baik \\
\hline
\end{tabular}




\begin{tabular}{|c|c|c|c|}
\hline 2 & $\begin{array}{lcccc}\text { Penyampaian } & \text { materi } & \text { oleh } & \text { dosen } & \text { dalam } \\
\text { pembelajaran } & \text { daring } & \text { (online) } & \text { dapat } & \text { dipahami } \\
\text { dengan jelas } & & & & \end{array}$ & $69 \%$ & Baik \\
\hline 3 & $\begin{array}{l}\text { Pemanfaatan atau penggunaan fitur video (video } \\
\text { conference) dan obrolan (live chat) pada saat } \\
\text { pembelajaran daring (online) }\end{array}$ & $75 \%$ & Baik \\
\hline 4 & $\begin{array}{l}\text { Memberikan kesempatan kepada mahasiswa untuk } \\
\text { bertanya dan memberikan pendapat pada saat } \\
\text { pembelajaran daring (online) }\end{array}$ & $89 \%$ & $\begin{array}{c}\text { Sangat } \\
\text { Baik }\end{array}$ \\
\hline 5 & $\begin{array}{l}\text { Koneksi/jaringan internet di rumah mendukung } \\
\text { untuk digunakan dalam pembelajaran daring } \\
\text { (online) }\end{array}$ & $62 \%$ & Baik \\
\hline 6 & $\begin{array}{l}\text { Penggunaan jenis koneksi internet "Paket Data" } \\
\text { lebih sering digunakan dalam pembelajaran daring } \\
(\text { online })\end{array}$ & $82 \%$ & $\begin{array}{c}\text { Sangat } \\
\text { Baik }\end{array}$ \\
\hline 7 & $\begin{array}{l}\text { Inovasi dosen pada saat menyampaikan materi } \\
\text { pembelajaran daring (online) }\end{array}$ & $75 \%$ & Baik \\
\hline 8 & $\begin{array}{l}\text { Penyimpanan materi pembelajaran secara online di } \\
\text { aplikasi Sistem Informasi Pembelajaran Daring } \\
\text { (Sipedar) UST atau aplikasi lainnya }\end{array}$ & $81 \%$ & $\begin{array}{c}\text { Sangat } \\
\text { Baik }\end{array}$ \\
\hline 9 & $\begin{array}{l}\text { Pelaksanaan diskusi pada saat pembelajaran daring } \\
\text { (online) }\end{array}$ & $63 \%$ & Baik \\
\hline 10 & $\begin{array}{l}\text { Jumlah tugas-tugas yang diberikan pada saat } \\
\text { pembelajaran daring (online) }\end{array}$ & $63 \%$ & Baik \\
\hline 11 & $\begin{array}{l}\text { Kestabilan jaringan koneksi internet pada saat } \\
\text { akses ke Sistem Informasi Pembelajaran Daring } \\
\text { (Sipedar) UST atau aplikasi lainnya }\end{array}$ & $72 \%$ & Baik \\
\hline 12 & $\begin{array}{l}\text { Waktu pelaksanaan perkuliahan/pembelajaran } \\
\text { daring (online) dilaksanakan secara tepat waktu (on } \\
\text { time) }\end{array}$ & $77 \%$ & Baik \\
\hline & Rata-rata & $\mathbf{7 4} \%$ & Baik \\
\hline
\end{tabular}


Berdasarkan penjelasan landasan teori dan hasil survei di atas diketahui bahwa sistem pembelajaran daring (online) memiliki beberapa kelebihan sehingga dapat mempengaruhi efektivitas pembelajaran daring (online), khususnya pada mata kuliah Pendidikan Agama Islam. Kelebihan-kelebihan ini mencakup beberapa hal, di antaranya:

\section{Mempermudah Interaksi Pembelajaran Di Mana dan Kapan Saja}

Sistem pembelajaran daring dapat dilaksanakan di mana dan kapan saja, mahasiswa dan dosen tidak terkendala oleh tempat dan waktu sehingga tetap dapat melaksanakan kegiatan perkuliahan atau pembelajaran. Pembelajaran daring merupakan suatu inovasi pendidikan yang memanfaatkan teknologi informasi dalam kegiatan pembelajaran.

Kemampuan seorang dosen maupun mahasiswa dalam menggunakan dan memanfaatkan teknologi informasi sangat mempengaruhi efektivitas pembelajaran daring, sehingga diperlukan media atau aplikasi yang mudah digunakan. Dalam hal ini, Universitas Sarjanawiyata Tamansiswa Yogyakarta sedang mengutamakan penggunaan aplikasi Sistem Informasi Pembelajaran Daring (Sipedar).

Adapun hasil survei dari aspek kemudahan dalam penggunaan aplikasi Sistem Informasi Pembelajaran Daring (Sipedar) UST untuk pembelajaran daring (online) mencapai 76\% atau masuk dalam kategori "Baik", perlu diketahui bahwa salah satu unsur penting dalam pembelajaran daring (online) yakni adanya kemudahan dalam menggunakan atau mengoperasikan aplikasi atau media pembelajaran. Sehingga dengan kemudahan ini dapat mempermudah interaksi antara dosen dan mahasiswa.

Hal ini juga akan memberikan kenyamanan bagi dosen dan mahasiswa ketika melaksanakan pembelajaran daring (online). Adanya kenyamanan ini dapat berperan dalam meningkatkan efektivitas pembelajaran daring (online) mata kuliah Pendidikan Agama Islam;

Penyampaian materi oleh dosen dalam pembelajaran daring (online) dapat dipahami dengan jelas mencapai 69\% atau masuk dalam kategori "Baik". Artinya, penggunaan aplikasi Sipedar yang mudah dan materi yang disampaikan oleh dosen dapat diterima atau dipahami dengan jelas sehingga menciptakan interaksi pembelajaran yang baik di mana dan kapan saja. Meskipun dalam penyampaian materi melalui tatap layar (virtual), namun materi Pendidikan Agama Islam harus dapat 
tersampaikan dengan sebaik-baiknya, mengingat materinya yang luas dengan ketersedian waktu perkuliahan yang terbatas.

Apabila materi pembelajaran dapat diterima dan dipahami dengan jelas oleh mahasiswa, maka akan meningkatkan keberhasilan atau efektivitas dalam kegiatan pembelajaran daring (online). Dengan demikian dapat disimpulkan bahwa berdasarkan dua indikator di atas diperoleh rata-rata sebanyak $73 \%$ atau masuk dalam kategori "Baik", artinya pembelajaran daring (online) telah terbukti mempermudah interaksi pembelajaran di mana dan kapan saja.

\section{Meningkatkan Interaksi Pembelajaran}

Meskipun telah tercipta interaksi pembelajaran yang baik, namun masih diperlukan upaya untuk meningkatkannya. Interaksi pembelajaran yang semakin baik akan meningkatkan efektivitas pembelajaran, termasuk dalam pembelajaran daring (online). Untuk meningkatkan interaksi dalam pembelajaran daring dapat dilakukan dengan memanfaatkan atau memaksimalkan fitur-fitur yang telah tersedia pada aplikasi pembelajaran daring (online).

Adapun hasil survei pada aspek Pemanfaatan atau penggunaan fitur video (video conference) dan obrolan (live chat) pada saat pembelajaran daring (online) mencapai 75\% atau masuk dalam kategori "Baik", artinya dosen telah menggunakan dan memanfaatkan fitur-fitur yang tersedia pada aplikasi atau media pembelajaran daring (online) dengan baik.

Dosen memberikan kesempatan kepada mahasiswa untuk bertanya dan memberikan pendapat pada saat pembelajaran daring (online) mencapai 89\% atau masuk dalam kategori "Sangat Baik", artinya pembelajaran daring (online) yang baik bukan pembelajaran yang satu arah, namun pembelajaran dua arah. Sehingga mahasiswa juga berkesempatan untuk aktif, seperti halnya ketika pembelajaran dilaksanakan di kelas (on site). Hal ini tentu akan meningkatkan efektivitas kegiatan pembelajaran daring (online) pada mata kuliah Pendidikan Agama Islam.

Dengan demikian, dapat disimpulkan bahwa pemanfaatan fitur-fitur yang tersedia dalam aplikasi pembelajaran daring (online) dan pemberian kesempatan kepada mahasiswa untuk berperan aktif dalam pembelajaran dapat sangat baik meningkatkan interaksi pembelajaran daring (online). Mengaktifan atau menggunakan video secara langsung pada saat pembelajaran daring (online), akan menciptakan tatap muka secara virtual yang sangat baik. 
Hal ini juga akan terjadi adanya feed back antara dosen dan mahasiswa dalam pembelajaran, sehingga pembelajaran daring (online) akan lebih menyenangkan dan menarik antusias belajar mahasiswa, serta materi pembelajaran juga dapat tersampaikan kepada mahasiswa dengan lebih baik.

\section{Memiliki Jangkauan yang Lebih Luas}

Sistem pembelajaran daring (online) dapat dilakukan dengan menggunakan dan memanfaatkan berbagai macam aplikasi sebagai media belajar yang dapat diakses melalui smartphone, tablet, laptop, ataupun gadget yang dapat terhubung dengan internet. Sehingga mahasiswa dapat belajar kapan dan di mana saja tanpa terbatas oleh jarak, ruang, dan waktu. Adanya jaringan internet inilah yang menjadikan jangkauan pembelajaran daring (online) menjadi lebih luas.

Namun, perlu diingat bahwa komponen utama dalam pembelajaran daring (online) adalah adanya jaringan internet. Kondisi jaringan internet setiap daerah berbeda-beda, hal ini dipengaruhi oleh ketersediaan dan kualitas jaringan provider yang ada atau belum adanya fasilitas jaringan internet yang lebih stabil, seperti WiFi.

Berkaitan dengan pembelajaran daring (online) yang memiliki jangkauan luas, yang juga dipengaruhi oleh jaringan koneksi internet dapat dilihat dari hasil survei bahwa koneksi/jaringan internet di rumah mendukung untuk digunakan dalam pembelajaran daring (online) mencapai 62\% atau masuk dalam kategori "Baik" artinya ketersediaan fasilitas yang ada di rumah, baik berupa jaringan General Packet Radio Service (GPRS) maupun Wirelless Fidelity (WiFi) mendukung secara baik untuk pembelajaran daring (online).

Kemudian penggunaan jenis koneksi internet "Paket Data" lebih sering digunakan dalam pembelajaran daring (online) mencapai $82 \%$ atau masuk dalam kategori "Sangat Baik" artinya jaringan "Paket Data" atau GPRS lebih sering digunakan oleh mahasiswa untuk mengikuti pembelajaran daring (online) dari pada jaringan WiFi. Oleh karena itu, apabila menggunakan jaringan GPRS yang sinyalnya sedang lemah, maka dapat mempengaruhi pelaksanaan pembelajaran daring (online).

Dengan demikian dapat disimpulkan bahwa berdasarkan dua indikator di atas diperoleh rata-rata sebanyak 72\% atau masuk dalam kategori "Baik", artinya sistem pembelajaran daring (online) telah terbukti dapat menjangkau secara lebih luas atau tidak terbatas oleh ruang dan waktu seperti halnya sistem pembelajaran dikelas (on site) yang bersifat terbatas. 


\section{Mempermudah Penyempurnaan dan Penyimpanan Materi Pembelajaran}

Melalui pembelajaran daring (online) materi-materi pembelajaran yang disampaikan oleh dosen nantinya akan dihimpun dan tersimpan dalam aplikasi atau media pembelajaran daring yang dapat diakses oleh mahasiswa, sehingga akan memudahkan mahasiswa untuk mengunduhnya di mana dan kapan saja. Oleh karena itu, dosen harus bisa berpikir kreatif untuk menyusun materi pembelajaran dan menyesuaikannya dengan aplikasi atau media pembelajaran daring yang cocok. Berkaitan dengan hal ini, dilakukan survei dan hasilnya menunjukkan bahwa inovasi dosen pada saat menyampaikan materi pembelajaran daring (online) mencapai $75 \%$ atau masuk dalam kategori "Baik", artinya dosen telah berupaya untuk berinovasi pada saat pembelajaran daring dan hasilnya ditunjukkan dengan pernyataan dari mahasiswa yang mayoritas menyatakan baik.

Kemudian terkait penyimpanan materi pembelajaran secara online di aplikasi Sistem Informasi Pembelajaran Daring (Sipedar) UST atau aplikasi lainnya mencapai 81\% atau masuk dalam kategori "Sangat Baik", artinya pernyataan tentang pembelajaran daring (online) memberi kemudahan dalam penyimpanan materi pembelajaran Pendidikan Agama Islam dapat dibuktikan dengan kriteria penilaian sangat baik.

Selain itu, materi pembelajaran yang telah diunggah atau tersimpan dalam aplikasi dapat digunakan sebagai pendukung bahan belajar mandiri mahasiswa. Sehingga hal ini bernilai positif terhadap kualitas dan efektivitas pembelajaran daring (online) pada mata kuliah Pendidikan Agama Islam. Dengan demikian dapat disimpulkan bahwa berdasarkan dua indikator di atas diperoleh rata-rata sebanyak 78\% atau masuk dalam kategori "Baik", artinya sistem pembelajaran daring (online) telah terbukti dapat mempermudah penyempurnaan dan penyimpanan materi pembelajaran. Sehingga materi maupun penjelasan materi pembelajaran yang disampaikan oleh dosen dapat terekam melalui aplikasi atau media pembelajaran daring lainnya.

Selain itu, sistem pembelajaran daring pada masa pandemi ini juga masih banyak kekurangsiapan dan proses penyesuaian yang masih terus diupayakan seperti literasi teknologi yang belum sepenuhnya dikuasai oleh pendidik maupun peserta didik. Namun, seiring berjalannya waktu kekurangan seperti ini dapat segera teratasi dengan semakin terbiasanya dosen dan mahasiswa menggunakan platform pembelajaran 
daring (online), serta dilakukannya sosialisasi kepada mahasiswa dan pelatihan bagi dosen.

Kemudian, kualitas koneksi jaringan internet yang tidak sama di setiap masingmasing wilayah juga merupakan faktor yang fundamental, mengingat sistem pembelajaran daring (online) sangat bergantung pada adanya koneksi jaringan internet. Kekurangan-kekurangan dalam pembelajaran daring (online) perlu diidentifikasi, supaya segera ditemukan solusinya. Karena, hal ini tentu dapat mempengaruhi efektivitas dan kualitas penerimaan materi pembelajaran, khususnya materi Pendidikan Agama Islam (PAI).

Langkah awal dalam proses identifikasi kendala pelaksanaan pembelajaran daring (online) dalam situasi pandemi Covid-19 dimulai dengan memberikan beberapa pertanyaan seperti: apakah pelaksanaan diskusi pada saat pembelajaran daring (online) berjalan monoton atau kurang menarik? Hasil survei menjelaskan bahwa pada aspek pelaksanaan diskusi secara online ini mencapai 63\% atau masuk dalam kategori "Baik", artinya meskipun diskusi dilaksanakan secara online, tentu suasananya berbeda dengan pada saat diskusi dikelas (on-site), namun hal ini tidak menjadi kendala yang signifikan.

Pertanyaan tentang apakah dosen banyak memberikan tugas pada saat pembelajaran daring (online), hasil survei menjelaskan bahwa jumlah tugas-tugas yang diberikan oleh dosen mencapai 63\% atau masuk dalam kategori "Baik", artinya tugastugas yang selama ini diberikan oleh dosen kepada mahasiswa pada saat pembelajaran daring (online) tidak menjadi beban atau kendala bagi mereka. Hal ini dibuktikan dengan capaian pada aspek pemberian tugas-tugas masuk dalam kategori baik.

Kemudian pertanyaan terkait jaringan koneksi internet stabil pada saat akses ke Sistem Informasi Pembelajaran Daring (Sipedar) UST atau aplikasi lainnya, hasil survei menjelaskan bahwa kestabilan jaringan koneksi internet pada saat pembelajaran daring (online) mencapai 72\% atau masuk dalam kategori "Baik", artinya meskipun kondisi jaringan koneksi internet masing-masing daerah berbeda-beda, namun secara garis besar dapat digunakan untuk mengakses Sipedar UST atau aplikasi media pembelajaran daring lainnya secara stabil.

Terkait waktu pelaksanaan perkuliahan/pembelajaran daring (online) dilaksanakan secara tepat waktu (on time), hasil survei menerangkan bahwa pelaksanaan pembelajaran daring dilaksanakan secara on time mencapai $77 \%$ atau 
masuk dalam kategori "Baik", artinya pelaksanaan perkuliahan secara garis besar dapat terlaksana sesuai waktu yang telah ditetapkan.

Hal ini didukung oleh ketersediaan waktu dan jadwal perkuliahan yang jelas, sehingga dapat meminimalisir molornya waktu perkuliahan, baik dari aspek mulainya perkuliahan maupun berakhirnya perkuliahan. Selain itu, juga diperlukan ketegasan dan kebijaksanaan dosen bila menemukan mahasiswa yang sering terlambat mengikuti perkuliahan/pembelajaran daring (online).

Berdasarkan penjelasan di atas dapat disimpulkan bahwa kendala-kendala dalam pembelajaran daring (online) pada mata kuliah Pendidikan Agama Islam berada pada dua indikator yang meliputi: Pertama, masih minimnya skor penilaian terkait dengan pelaksanaan diskusi online, yakni hanya mencapai 63\%. Meskipun sudah masuk dalam kategori baik. Namun, apabila hal ini tidak segera dievaluasi maka dapat mengurangi efektivitas pembelajaran daring (online) pada mata kuliah Pendidikan Agama Islam. Proses diskusi yang dirasa monoton atau biasa saja dapat menimbulkan kebosanan dan menurunkan semangat belajar mahasiswa.

Kedua, berkaitan dengan tugas-tugas yang diberikan oleh dosen kepada mahasiswa yang hanya mencapai 63\%. Meskipun hal ini juga sudah masuk dalam kategori baik. Namun, hal ini masih dirasa kurang maksimal. Karena pembelajaran daring (online) dapat menjadikan aktivitas belajar mahasiswa tidak terkontrol (bebas), sehingga diperlukan tugas-tugas yang relevan untuk memantau perkembangan belajar mahasiswa dan tentunya tugas-tugas yang diberikan harus dengan porsi yang pas, artinya tidak menjadikan beban pada mahasiswa.

\section{SIMPULAN DAN SARAN}

\section{Simpulan}

Temuan ini menunjukkan bahwa sistem pembelajaran daring (online) yang selama ini dilakukan pada mata kuliah Pendidikan Agama Islam dapat berjalan secara baik. Hal ini dapat dibuktikan dari hasil survei yang menunjukkan dari keseluruhan indikator dalam penelitian ini mencapai rata-rata 74\% atau masuk dalam kategori "Baik", artinya sistem pembelajaran daring (online) dari aspek media (aplikasi) yang digunakan selama ini pada mata kuliah Pendidikan Agama Islam sudah baik. Meskipun demikian, tetap diperlukan evaluasi atau pengkajian secara berkala supaya efektivitas pembelajaran pada mata kuliah Pendidikan Agama Islam dapat lebih meningkat lagi. 
Namun, sistem pembelajaran ini juga memiliki beberapa kekurangan, seperti: kendala yang fundamental terkait dengan kualitas dan fasilitas jaringan koneksi internet masing-masing daerah yang berbeda-beda. Sehingga menuntut dosen untuk menyusun formula atau berinovasi dalam pelaksanaan pembelajaran daring (online) supaya dapat berjalan efektif.

Pernah ditemukan pada mahasiswa yang tempat tinggalnya jaringan koneksi internetnya tidak stabil, kemudian mereka membuat sebuah video presentasi dan nantinya akan diputarkan oleh teman-temannya yang jaringan koneksi internetnya stabil pada saat pembelajaran daring (online). Artinya, kendala-kendala seperti ini sebetulnya dapat diminimalisir dengan daya kreatifitas mahasiswa.

\section{Saran}

Kajian ini masih terbatas atau berfokus pada metodologi dan aplikasi media pembelajaran yang digunakan dalam pembelajaran daring (online) pada mata kuliah Pendidikan Agama Islam. Artinya, masih dapat dilakukan penelitian yang lebih mendalam lagi dengan mengukur efektivitas pembelajaran daring (online) berdasarkan prestasi atau hasil belajarnya. Atau, dapat mencari korelasi antara media pembelajaran daring (online) yang efektif digunakan selama ini dengan prestasi hasil belajar mahasiswa.

\section{DAFTAR PUSTAKA}

Amin, A.R. (2014). Sistem Pembelajaran Pendidikan Agama Islam pada Perguruan Tinggi Umum. Yogyakarta: Deepublish.

Fehr, A., \& Perlman, S. (2015). Coronaviruses: An Overview of Their Replication and Pathogenesis, 1-23.

Hamalik, O. (2003). Manajemen Belajar di Perguruan Tinggi: Pendekatan Sistem Kredit Semester (SKS). Bandung: Sinar Baru Algensindo.

Hikmat, Dkk. (2020). Efektivitas Pembelajaran Daring Selama Masa Pandemi Covid-19: Sebuah Survey Online. Karya Tulis Ilmiah Masa Work From Home Covid-19, 1-7.

Khasanah, D.R.A.U. (2020). Pendidikan dalam Masa Pandemi Covid-19. Jurnal Sinestesia, 10(1), 41-48.

Majid, A., Andayani, D. (2005). Pendidikan Agama Islam Berbasis Kompetensi: Konsep dan Implementasi Kurikulum 2004. Bandung: PT Remaja Rosdakarya.

Makbuloh, M., (2011). Pendidikan Agama Islam: Arah Baru Pengembangan Ilmu dan Kepribadian di Perguruan Tinggi. Jakarta: PT Raja Grafindo Persada. 
Pujilestari, Y. (2020). Dampak Positif Pembelajaran Online dalam Sistem Pendidikan Indonesia Pasca Pandemi Covid-19. 'Adalah: Buletin Hukum dan Keadilan, 4(1), 49-56.

Rifa'I, I., Dkk. (2020). Dampak dan Pencegahan Wabah Covid-19: Perspektif Sains dan Islam, 1-10.

Sadikin, A., \& Hamidah, A. (2020). Online Learning in the Middle of the Covid-19 Pandemic. Biodik: Jurnal Ilmiah Pendidikan Biologi, 6(2), 214-224.

Sutrisno, \& Suyatno. (2015). Pendidikan Islam di Era Peradaban Modern. Jakarta: Prenadamedia Group.

Suyono. (2020). Manajemen Pembelajaran Berbasis Daring dalam Rangka Memutus Mata Rantai Penularan Covid-19 di Perguruan Tinggi Swasta Lembaga Layanan Perguruan Tinggi (LLDIKTI) Wilayah VII. Ed-Humanistics, 5(1), 662-666.

Syarifudin, A.S. (2020). Implementasi Pembelajaran Daring untuk Meningkatkan Mutu Pendidikan sebagai Dampak Diterapkannya Social Distancing. Metalingua: Jurnal Pendidikan Bahasa dan Sastra Indonesia, 5(1), 31-34.

Widiyono, A. (2020). Efektifitas Perkuliahan Daring (Online) pada Mahasiswa PGSD di Saat Pandemi Covid-19. Jurnal Pendidikan, 8(2), 169-177.

Zhafira, N.H., Dkk. (2020). Persepsi Mahasiswa Terhadap Perkuliahan Daring sebagai Sarana Pembelajaran Selama Masa Karantina Covid-19. Jurnal Bisnis dan Kajian Strategi Manajemen, 4(1), 37-45. 